\title{
PENEGAKAN HUKUM TERHADAP PENCURIAN IKAN (ILLEGAL FISHING) DI WILAYAH PERBATASAN PROVINSI KEPULAUAN RIAU
}

\author{
Wasrizal* \\ Pemerintah Provinsi Kepulauan Riau
}

\begin{abstract}
As a border region, Riau Islands Province is very vulnerable to illegal fishing cases. Such cases can occur in the territorial sea as well as in exclusion economic zones or in the open sea boundary region. The purpose of this study is to record which agencies have authority handling illegal fishing in the border region of Riau Islands Province. It also analyzes obstacles and finds solutions for the authorities relating to illegal fishing in the Riau Islands border region by using sociological legal research methods. The research finds that the agencies that manage cases of illegal fishing are the Directorate of Water Police of Riau Islands Regional Police, Riau Islands Province Marine and Fisheries Service, Fisheries Court at Tanjungpinang State Courts and Indonesian Riau Islands Navy Force. Each of them has their respective authority in accordance with the provisions of the applicable legislation
\end{abstract}

Keywords : Illegal fishing, law enforcement, Riau Island Province

\begin{abstract}
Abstrak
Sebagai wilayah perbatasan Provinsi kepulauan Riau sangat rentan akan kasus pencurian ikan. Kasus tersebut dapat terjadi di laut teritorial maupun di wilayah zona ekonomi eksklusi maupun di laut lepas wilayah perbatan. Tujuan penelitian ini adalah untuk menginventarisir instansi yang mempunyai kewenangan dalam hal terjadinya kasus pencurian ikan di wilayah perbatasan Provinsi Kepulauan Riau. Peneliti ini juga menganalisis hambatan dan menemukan solusi bagi instansi berwenang terkait pencurian ikan di wilayah perbatasan Provisi Kepulauan Riau, dengan menggunakan metode penelitian hukum sosiologis. Penelitian ini menemukan bahwa instasi yang menangani kasus pencurian ikan diantaranya adalah Direktorat Polisi Air Polda Kepulauan Riau, Dinas Kelautan dan Perikanan Provinsi Kepulauan Riau, Pengadilan Perikanan pada Pengadialan Negeri Tanjungpinang dan TNI Angkatat Laut Kepulauan Riau. Instansi tersebut mempunyai kewenangan masing-masing sesuai dengan ketentuan perundang-undangan yang berlaku.
\end{abstract}

Kata Kunci: Pencurian ikan, Penegakan hukum, Provinsi Kepulauan Riau

* Alamat Korespondensi : wasriza1007@gmail.com 


\section{A. Latar Belakang Masalah}

Kondisi geografis Indonesia sebagai negara yang dua pertiganya adalah wilayah perairan laut yang terdiri dari laut pesisir, laut lepas, teluk, dan selat memiliki panjang pantai $95.181 \mathrm{Km}$, dengan luas perairan 5,8 juta $\mathrm{km} /$ persegi. ${ }^{1}$ Kondisi geografis tersebut memberikan kekayaan berupa sumber daya laut dan ikan bagi masyarakat Indonesia. Perairan laut yang luas dan kaya akan jenis potensi kelautan kurang lebih 4 milliar USD/ Tahun. ${ }^{2}$ Daerah perbatasan sering dikatakan sebagai daerah yang cepat mengalami kemajuan karena sangat dekat dengan negara lain. Seperti Provinsi Kepulauan Riau yang berbatasan dengan Singapura, Malaysia dan Kemboja dan Vietnam, namun disisi lainya, sebagai daerah perbatasan juga`sering diasumsikan sebagai kawasan yang rawan pemberontakan, pusat kegiatan ilegal, terbelakang semata`sehingga kurang menarik bagi kegiatan investasi dan ekonomi. Dalam hal ini hal yang dilihat tentunya dari satu pendekatan yaitu pendekatan keamanan. ${ }^{3}$ Khusus wilayah Kepulauan Riau sangat rentan dengan kasus ilegal fishing atau pencurian ikan yang selanjutnya dalam penelitian ini kita akan menggunakan itilah pencurian ikan, dimana ketika potensi alam yaitu potensi laut kita, jika terus dicuri oleh negara lain akan membawa kerugian untuk masyarakat Kepulauan Riau, karena kapal kapal luar telah mengambil banyak ikan ikan yang ada di laut kita.

Potensi laut tersebut apabila diusahakan secara optimal dengan tetap berpegang pada penangkapan yang lestari akan memberikan dampak: ${ }^{4}$

1. Meningkatnya devisa negara hasil ekspor komoditi perikanan laut

2. Meningkatnya gizi khususnya protein hewani bagi rakyat

3. Meningkatnya penghasilan dan pendapatan nelayan.

Dengan dampak yang sangat besar seperti ini tidak ada alasan lagi bagi Pemerintah untuk tidak serius mengelola sumber daya kelautan yang dimiliki Indonesia sebagai negara kepulauan. Kondisi strategis Kepulauan Riau ini menarik bagi kapalkapalpenangkapan ikan asing yang dengan illegal masuk ke dalam perairan Indonesia untuk melakukan tindak pidana pencurian ikan, dengan wilayah yang $97 \%$ adalah lautan tidaklah mudah bagi pemerintah setempat dan perairan Kepulauan Riau yang berdekatan dengan Negara tetangga menjadi zona pencurian ikan di wilayah laut Kepulauan Riau. Mulai dari Zona Ekomoni Ekslusif (ZEE) hingga laut teritorial adalah wilayah yang rawan terjadi dalam pencurian ikan oleh negara asing, dalam hal ini Kepulauan Riau menjadi salah satu tempat di Indonesia yang menjadi sangat rawan dalam pencurian ikan oleh nelayan asing, tercatat 242 kapal asing yang tertangkap di wilayah Indonesia lebih dari setengahnya ditangkap di wilayah Kepulauan Riau yang

\footnotetext{
1 Marhaeni Ria Siombo, Hukum Perikanan Nasional dan International, Jakarta, Gramedia Pustaka Utama, 2010, hlm 1

${ }^{2}$ http://statistik.kkp.go.id/index.php/arsip/c/?category_id=3 Diakses tanggal 15 April 2018 jam 15.00

${ }^{3}$ Edy Sofyan, Kebijakan Pertahanan Pertanahan di Perbatasan Maritim, Majalah suara Perbatasan, Edisi IX Juni 2016

4 Op.cit Marhaeni Ria Siombo.
} 
menyebabkan kerugian negara hingga Rp 160 milliar $^{5}$, maka karena banyaknya kasus pencurian ikan di wilayah Kepulauan Riau sehingga membuat pemerintah membentuk Peradilan Perikanan di Pengadilan Negeri Tanjung Pinang. Pada tahun 2013 tidak kurang dari 39 kapal asing memasuki perairan Indonesia dan menangkap ikan secara ilegal, kapal-kapal tersebut berasal dari beberapa negara tetangga seperti, Malaysia, Philipina, Vietnam, Myanmar bahkan hingga Korea, Jepang, dan China. Bukan hanya merugikan negara, keberadaan para nelayan-nelayan illegal ini juga berpengaruh terhadap ekosistem laut dan keberlanjutan sumber pangan perikanan. ${ }^{6}$

Kementrian Kelautan dan Perikanan (KKP) mencatat banyak kapal berbendera asing masuk dan masuk mencuri ikan atau pencurian ikan di laut Indonesia. Tercatat, pencuri ikan asal Vietnam paling banyak yang tertangkap mencuri ikan di perairan Indonesia di lain itu Thailand, Philipina dan Malaysia juga termasuk. Tercatat pada tahun 2013 Vietnam 17 kapal ditangkap, Malaysia 14 kapal, Philipina 9 kapal dan Thailand sebanyak 4 kapal. $^{7}$ Pencurian ikan juga mengkategorikan bahwa kapal nasional yang yang tidak mempunyai Surat Izin Penangkapan Ikan (SIPI) juga termasuk dalam pencurian ikan selain dari nelayan asing yang mencuri ikan di wilayah perairan Indonesia. Peradilan perikanan di Indonesia pertama kali di bentuk di Jakarta pada Tahun 2004. Pembentukan peradilan perikanan dilanjutkan di Pengadilan Negeri Jakarta Utara, Pengadilan Negeri Medan, Pengadilan Negeri Pontianak, Pengadilan Negeri Belitung, dan Pengadilan Negeri Tual. Dimana pada Tahun 2010 pengadilan perikanan dibentuk di Pengadilan Negeri Tanjung pinang dan Pengadilan Negeri Ranai. Dibentuknya pengadilan perikanan di suatu wilayah dikarenakan tindak pidana pencurian ikan sudah marak terjadi, sehingga diperlukannya pengadilan perikanan. Terlebih lagi di wilayah Kepulauan Riau khususnya Kota Tanjung Pinang yang bersinggungan dengan batas-batas Negara, wilayah seperti inilah yang menjadi rawan dalam pencurian ikan.

\section{B. Rumusan Masalah}

Dari latar belakang yang telah dituangkan diatas, maka perumusan permasalahannya adalah :

1. Instansi manakah yang mempunyai kewenangan dalam hal terjadinya kasus pencurian ikan di wilayah perbatasan Provinsi Kepulauan Riau?

\footnotetext{
${ }^{5}$ http://www.kkp.go.id/index.php/arsip/c/1383/Perairan-Natuna-Paling-Rawan-Pencurian-IkanolehKapal-Asing-/ di akses pada tanggal 29 Maret Tahun 2018 Pukul 12.04 WIB.

${ }^{6}$ http://economormormy.okezone.com/read/2018 /01/07/320/923024/2013-39-kapal-asing-ilegalcuriikan-ri di akses pada tanggal 21 Maret tahun 2018 Pukul 16.00 WIB.

${ }^{7}$ http://finance.detik.com/read/2014/07/08/131735/2631219/4/malaysia-dan-vietnam-negaraasalpencuri-ikan-terbanyak-di-laut-ri diakses pada tanggal 29 Maret Tahun 2018 Pukul 19.00 WIB.
} 
2. Apakah tindakan yang dilakukan oleh instansi berwenang dalam penegakan hukum terhadap pihak yang melakukan pencurian ikan di wilayah perbatasan Provinsi Kepulauan Riau ?

3. Apakah hambatan dan solusi yang dihadapi instansi berwenang dalam penegakan hukum terkait pencurian ikan di wilayah perbatasan Kepulauan Riau ?

\section{Meode Penelitian}

Menurut Morris L. Cohen, penelitian hukum adalah sebuah proses menemukan hukum yang mengatur aktivitas pergaulan manusia, yang melibatkanaturan yang diberlakukan oleh Negara dan komentar yang menjelaskan atau menganalisis aturan ini, sebagaimana diterjemahkan penulis dari pernyataannya sebagai berikut:

"...Legal research is the process of finding the law that governs activities in human society, it involves locatingboth the rules which are enforced by the states and commentaries which explain or analyze these rule..."8

Metode penelitian yang peneliti gunakan dalam penelitian ini adalah metode pendekatan hukum sosiologis yaitu melihat masalah melalui penelitian hukum dengan melihat norma hukum yang ada dan masih berlaku tentatng penegakan hukum pencurian ikan di wilayah perbatasan Provinsi Kepulauan Riau. ${ }^{9}$

Pada tingkat perkembangan peradaban ilmu (hukum) seperti sekarang ini, mulai berkembang dengan pesatnya suatu cabang disiplin hukum yang secara otomatis dan intensif melakukan kajian terhadap aspek-aspek sosial dari hukum, yang kemudian kita kenal dengan study hukum dan masyarakat. ${ }^{10}$ Dalam penelitian hukum sosiologis, hukum dikonsepkan sebagai pranata sosial yang secara riil dikaitkan dengan variablevariable sosial yang ada. Terdapat berbagai jenis penelitian hukum sosiologis, diantaranya: (a). Penelitian berlakunya hukum: Penelitian efektifitas hokum, Penelitian dampak hukum. (b).Penelitian identifikasi hukum tidak tertulis.

Penelitian hukum sosiologis yang peneliti gunakan adalah metode penelitian hukum sosiologisatau sosiologi hukum yang menitik beratkan pada penanganan yang dilakukan oleh instasi instansi terkait yang memiliki kewenangan menangani kasus kasus illegal fishing yang tejadi di wilayah Provinsi Kepulauan Riau. Penelitian ini memiliki objek, dimana yang menjadi objek dalam penelitian hukum adalah insatansi instansi terkait dalam menangani kasus pencurian ikan di wilayah Provinsi Kepulauan Riau yaitu Dinas Kelautan dan Perikanan Provinsi Kepulauan Riau, TNI Angkatan Laut, Polisiair, dan Pengadilan Perikanan pada Negeri Tanjungpinang.

Data Primer adalah data yang diperoleh langsung dari subyek penelitian dengan mengenakan alat pengukuran atau alat pengambilan data langsung pada subjek sebagai

${ }^{8}$ Marzuki Peter Mahmud, 2009, Penelitian Hukum, Cet.5, Kencana, Jakarta, hlm .29

${ }^{9}$ Soerjono Soekanto,2006,Pengantar Penelitian Hukum,Universitas Indonesia (UI Press),Jakarta,hal 52.

${ }^{10}$ Ibid, hlm 72 
sumber informasi yang dicari. Data primer ini disebut juga dengan Data Tangan Pertama. Data Sekunder adalah data yang diperoleh lewat pihak lain, tidak langsung diperoleh oleh peneliti dari subjek penelitiannya. Data sekunder ini disebut juga dengan Data Tangan Kedua. Data Sekunder biasanya berwujud data dokumentasi atau data laporan yang telah tersedia. Data primer dan data sekunder, dapat pula digolongkan menurut jenisnya sebagai data kuantitatif yang berupa angka-angka dan data kualitatif yang berupa kategori-kategori. Data yang peneliti gunakan dalam penelitian ini adalah data primer dan data sekunder. Data primer yaitu yang di peroleh langsung dari masyarakat atau data yang didapat langsung dari lapangan. Data primer ini peneliti peroleh dari masyarakat dan instansi terkait dalam penangana kasus pencurian ikan di wilayah Provinsi Riau sebagai daerah perbatasan yang sangat rentan terjadinya pencurian ikan.

Metode analisis data yang penulis gunakan dalam Penelitian ini adalah Analisis Kualitatif pola-pola yang dianalisa adalah gejala-gejala masyarakat yang ditimbulkan oleh pemberlakuan suatu peraturan hukum. Teknik pengumpulan data berupa pengamatan, studi kasus dan wawancara. Data mentah yang telah dikumpulkan akan tidak berarti dan tidak ada gunanya, apabila tidak dilakukan analisa. Analisa data merupakan bagian yang amat penting dalam metode Penelitian ilmiah karena dengan analisa data tersebut diberi arti dan makna yang berguna dalam memecahkan masalah Penelitian.

Data mentah yang telah dikumpulkan perlu dipecahkan dalam kelompok-kelompok, data tersebut selanjutnya diseleksi, diklasifikasi secara sistematis, logis dan yuridis sehingga data tersebut mempunyai makna untuk menjawab permasalahan Penelitian. ${ }^{11}$

Metode analisis data yang peneliti gunakan dalam penelitian ini adalah yuridis kualitatif. Dengan pola-pola yang dianalisa adalah penanganan, penegakan hukum oleh instansi instansi terkait dalam menangani kasus pencurian ikan di kawasan perbatasan provinsi Kepulauan Riau. Teknik pengumpulan data berupa pengamatan observasi, studi kasus dan wawancara.

\section{Hasil Penelitian dan Pembahasan}

Pada Dinas Kelautan dan Perikanan Provinsi Kepulauan Riau peneliti melakukan wawancara pada Kapala seksi Pengawasan sumberdaya kelautan dan perikanan Bapak Sahrizan, ST. Pendapat beliau tentang kasus pencurian ikan yang terjadi di wilayah Kepulauan Riau pada saat ini mengalami penurunan setelah dilakukan kebijakan oleh Kementerian Kelautan dan Perikanan bahwa kapal kapal asing yang masuk di wilayah perairan Indonesia termasuk Kepulauan Riau harus dilakukan tindakan tegas tanpa ada toleransi berdasarkan peraturan perundang-undnagan yang berlaku mengacu pada Undang-Undang Nomor 45 Tahun 2009 terutama terhadap kapal-kapal asing yang

${ }^{11}$ Moh. Nasir, Metode Penulisan, Ghalia, Indonesia, hlm. 405 
masuk ke perairan Indonesia termasuk wilayah Provinsi Kepulauan Riau. Selanjutnya beliau berpendapat bahwa Dinas Kelautan dan Perikanan Provinsi Kepulauan Riau sangat berperan aktif dalam penanganan kasus pencurian ikan yang berada di wilayah kewenangan Provinsi Kepulauan Riau yaitu 0-12 mill laut sesuai dengan amanah Undang-Undnag Nomor 23 Tahun 20014 tentang Pemerintahan Daerah.

Pada Polda Kepri yaitu Direktorat Polisi Air peneliti melakukan wawancara pada Bapak Ahmad Wahyudi SH.,MH dengan hasil bahwa menurut beliau pencurian ikan dilakukan nelayan asing di wilayah Kepulauan Riau terjadi karena nelayan asing tidak dilengkapi dengan Sipi dan izin lainya. Terkait pencurian ikan sesuai amanat undangundang maka Polri diamanatkan sebagai penyidik pencurian ikan, dengan acuan Kitab Undang-Undang Hukum Acara Pidana pasal 6 menjelaskan penyidik adalah pejabat kepolisian dan Penyidik Pegawai Negeri Sipil, dan menurut Undang-Undang Nomor 45 Tahun 2009 tentang perubahan UU No 31 tahun 2004 tentang Perikanan. Hambatan yang dihadapi oleh direktorat Pol Air Polda Kepri menurut beliau adalah mencakup wilayah kepulauan Riau yaitu 95,5\% adalah lautan yang sangat luas, keterbatasana sarana dan prasarana armada yang kurang dan faktor cuaca serta personil yang terbatas.

Sepanjang tahun 2016 sampai dengan 2018 kasus pencurian ikan yang ditangani oleh Polda Kepdri adalah, 6 (enam) kasus di tahun 2016, 3 (tiga) kasus di tahun 2017 dimana 1 (satu) kasus diserahkan ke Dinas Kelautan dan Perikanan (DKP) Provinsi Kepulauan Riau dan 2 (dua ) kasus P 21. Sedangkan untuk tahun 2018 ada 7 (tujuh) Kasus pertanggal 27 September 2018. Terkait koordinasi dalam menangani kasus pencurian ikan, Polda Kepri berkkordinasi dengan PSDKP, TNI Angkatan Laut sesuai dengan amanat undang-undang. Dan koordinasi berjalan dengan baik, tak ada kendala yang berarti serius, Polda proses sampai ke Jaksa Penuntut Umum. Untuk semua kasus yang masuk sudah dapat diselesaikan dan yang tidak selesai Polda serahkan pada PSDKP.

Dari hasil wawancara yang peneliti lakukan, menurut Bapak Ahmad wahyudi,SH,MH. tentang dasar hukum yang menjadi acuan dalam penanganan pencurian ikan sudah cukup bagus, berpedoman pada KUHAP dan Undang-Undang Perikanan dan beliau memberikan masukan agar armada, personil, sarana dan prasarana yang menjalankan tugas memberantas pencurian ikan dilapangan diperbanyak, baik itu jumlah kapal dan jam patroli harus terus ditingkatkan. 


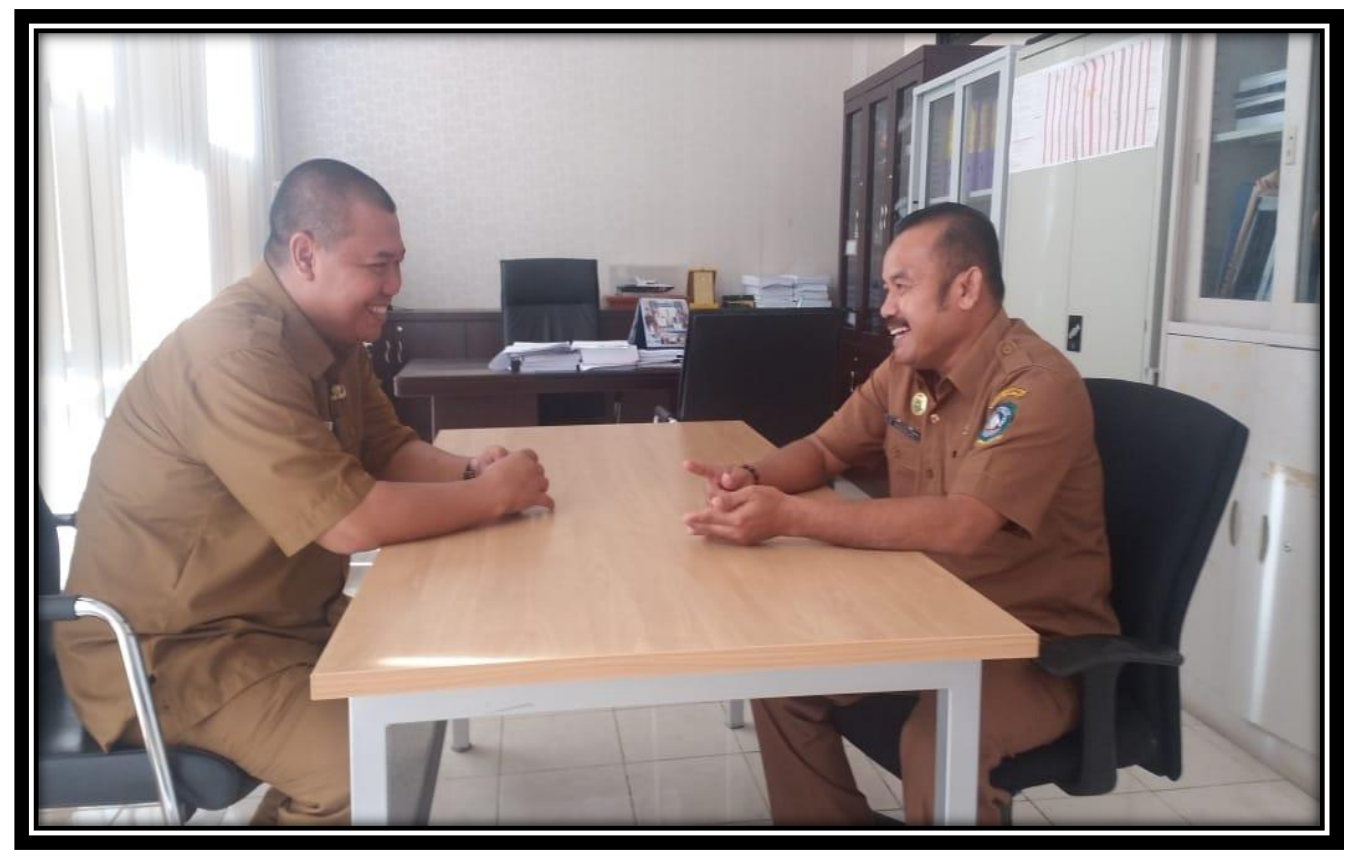

Gambar 1 hasil wawancara dengan Dinas Kelautan dan Perikanan Provinsi Kepulauan Riau

Pada Dinas Kelautan dan Perikanan Provinsi Kepulauan Riau peneliti melakukan wawancara pada Kapala seksi Pengawasan sumberdaya kelautan dan perikanan Bapak Sahrizan, ST. Pendapat beliau tentang kasus pencurian ikan yang terjadi di wilayah Kepulauan Riau pada saat ini mengalami penurunan setelah dilakukan kebijakan oleh Kementerian Kelautan dan Perikanan bahwa kapal kapal asing yang masuk di wilayah perairan Indonesia termasuk Kepulauan Riau harus dilakukan tindakan tegas tanpa ada toleransi berdasarkan peraturan perundang-undnagan yang berlaku mengacu pada Undang-Undang Nomor 45 Tahun 2009 terutama terhadap kapal-kapal asing yang masuk ke perairan Indonesia termasuk wilayah Provinsi Kepulauan Riau.

Selanjutnya beliau berpendapat bahwa Dinas Kelautan dan Perikanan Provinsi Kepulauan Riau sangat berperan aktif dalam penanganan kasus pencurian ikan yang berada di wilayah kewenangan Provinsi Kepulauan Riau yaitu 0-12 mill laut sesuai dengan amanah Undang-Undnag Nomor 23 Tahun 2014 tentang Pemerintahan Daerah. Untuk menangani kasus pencurian ikan menurut Bapak Sahrizan, ST. Dinas Kelautan dan Perikanan, instansi lain yang memiliki tugas menangani pencurian ikan adalah TNI AL, Satuan Polisi Air Polda Kepri, KKP dan Bea Cukai. Dan yang menjadi kewenangan dinas Kelautan dan Perikanan adalah pengawasan, penyelidikan dan penyidikan di wilayah 0-12 mil laut terhadap kapal yang berukuran 30 GT ke bawah. Dinas Kelautan dan Perikanan terus berkoordinasi dengan instansi terkait dan koordinasi berjalan tanpa hambatan. Dalam melaksanakan tugasnya Dinas Kelautan dan Perikanan mengacu pada Undang-Undang Nomor 23 Tahun 2014 tentang Pemerintah Daerah, Undang-Undang Nomor 45 Tahun 2009 tentang Perikanan, 
Undang-Undang Nomor 32 Tahun 2014 tentang Kelautan, Undang-Undang Nomor 27 Tahun 2007 tentang Pembangunan Wilayah Pesisir dan pulau pulau kecil, dan Undang-Undang Nomor 1 Tahun 2014 tentang Pembangunan Wilayah Pesisir dan pulau pulau kecil. Dinas Kelautan dan Perikanan memiliki kendala perlengkapan armada, terbatasnya personil dan pendanaan dalam melaksanakan tugasnya dan kasus yang pencurian ikan yang pernah ditangani sepanjang tahun 2016-2018 sebanyak 4 kasus diantaranya yaitu pada tahun 2016 menyelesaikan dangan pembinaan kasus kapal Minamaritim terkait sipi dan kasus kapal Harapan Jaya terkait SIB yang juga terselesaikan dengan pembinaan. Dan untuk menyelesaikan kasus pencurian ikan kendala yang dihadai hanya terkait administrasi kapal izin daerah dan jalur penangkapan.

Terkait dasar hukum yang digunakan sebagai acuan Bapak sahrizan, ST. berpendapat bahwa Undang-Undang Nomor 23 Tahun 2014 tentang Pemerintah Daerah, Undang-Undang Nomor 45 Tahun 2009 tentang Perikanan, Undang-Undang Nomor 32 Tahun 2014 tentang Kelautan, Undang-Undang Nomor 27 Tahun 2007 tentang Pembangunan Wilayah Pesisir dan pulau pulau kecil, dan Undang-Undang Nomor 1 Tahun 2014 tentang Pembangunan Wilayah Pesisir dan pulau pulau kecil cukup baik dan bisa dijadikan pedoman dalam penanganan dan pembinaan nelayan. Untuk menangani kasus pencurian ikan menurut Bapak Sahrizan, ST.

Dinas Kelautan dan Perikanan, instansi lain yang memiliki tugas menangani pencurian ikan adalah TNI AL, Satuan Polisi Air Polda Kepri, KKP dan Bea Cukai. Dan yang menjadi kewenangan dinas Kelautan dan Perikanan adalah pengawasan, penyelidikan dan penyidikan di wilayah 0-12 mil laut terhadap kapal yang berukuran 30 GT ke bawah. Dinas Kelautan dan Perikanan terus berkoordinasi dengan instansi terkait dan koordinasi berjalan tanpa hambatan.Dalam melaksanakan tugasnya Dinas Kelautan dan Perikanan mengacu pada Undang-Undang Nomor 23 Tahun 2014 tentang Pemerintah Daerah, Undang-Undang Nomor 45 Tahun 2009 tentang Perikanan, Undang-Undang Nomor 32 Tahun 2014 tentang Kelautan, Undang-Undang Nomor 27 Tahun 2007 tentang Pembangunan Wilayah Pesisir dan pulau pulau kecil, dan Undang-Undang Nomor 1 Tahun 2014 tentang Pembangunan Wilayah Pesisir dan pulau pulau kecil. 


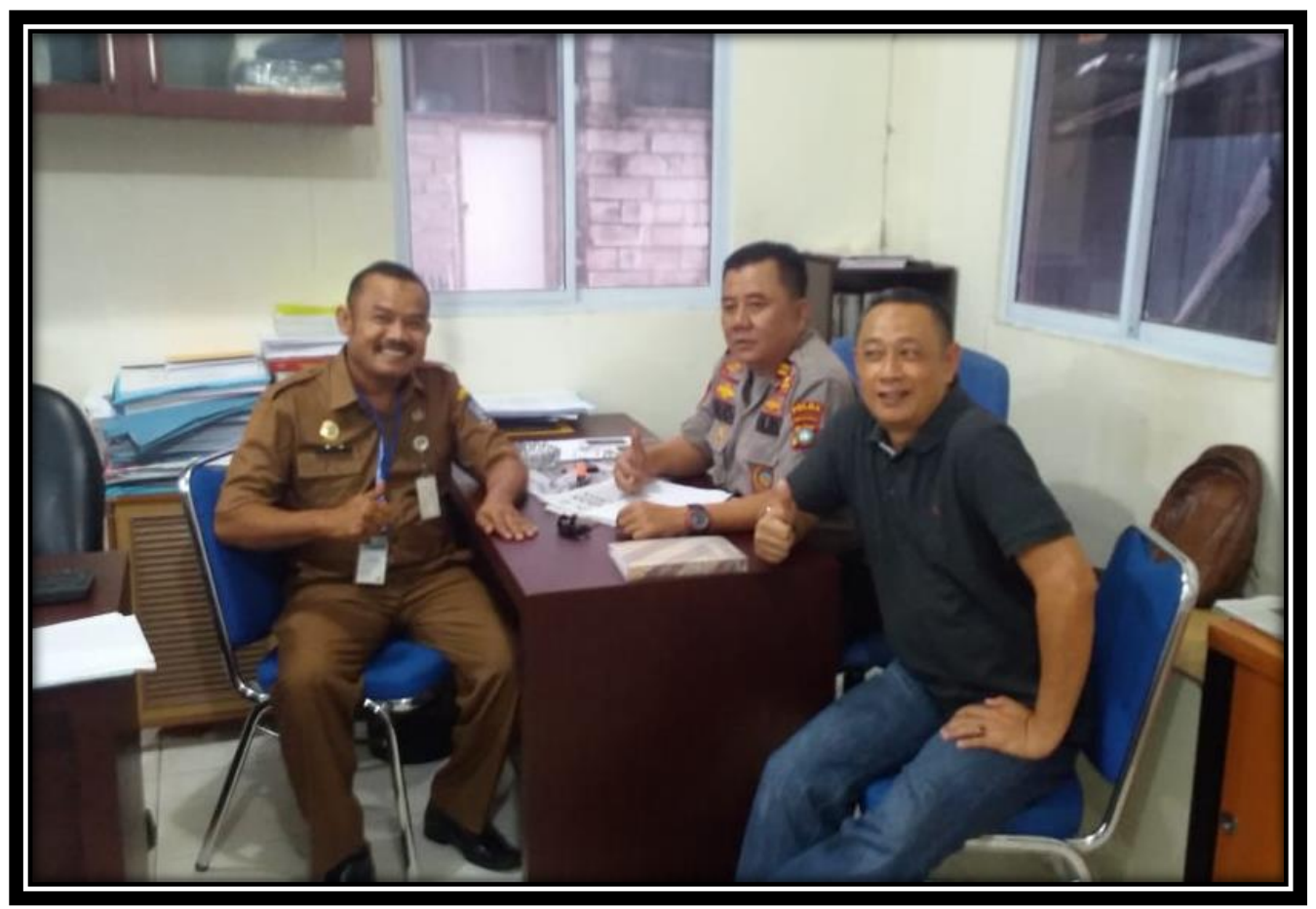

Gambar 2 hasil wawancara dengan Polisi Air Polda Kepulauan Riau

Dinas Kelautan dan Perikanan memiliki kendala perlengkapan armada, terbatasnya personil dan pendanaan dalam melaksanakan tugasnya dan kasus yang pencurian ikan yang pernah ditangani sepanjang tahun 2016-2018 sebanyak 4 kasus diantaranya yaitu pada tahun 2016 menyelesaikan dangan pembinaan kasus kapal Minamaritim terkait sipi dan kasus kapal Harapan Jaya terkait SIB yang juga terselesaikan dengan pembinaan. Dan untuk menyelesaikan kasus pencurian ikan kendala yang dihadai hanya terkait administrasi kapal izin daerah dan jalur penangkapan. Terkait dasar hukum yang digunakan sebagai acuan Bapak sahrizan, ST. berpendapat bahwa Undang-Undang Nomor 23 Tahun 2014 tentang Pemerintah Daerah, Undang-Undang Nomor 45 Tahun 2009 tentang Perikanan, Undang-Undang Nomor 32 Tahun 2014 tentang Kelautan, Undang-Undang Nomor 27 Tahun 2007 tentang Pembangunan Wilayah Pesisir dan pulau pulau kecil, dan Undang-Undang Nomor 1 Tahun 2014 tentang Pembangunan Wilayah Pesisir dan pulau pulau kecil cukup baik dan bisa dijadikan pedoman dalam penanganan dan pembinaan nelayan.

Peneliti juga melakukan wawancara pada Bapak Ir. Syafriyulis, MM sebagai Hakim Pengadilan Perikanan pada Pengadilan Negeri Tanjung pinang, hasil wawancara yang dilakukan pada bulan September 2018 ini, beliau berpendapat bahwa kasus pencurian ikan di daerah Provinsi Kepulauan Riau tiap tahunya bervariasi, mulai tahun 2010 sampai tahun 2018, pelanggaran pencurian ikan tertinggi terjadi pada tahun 2017 yaitu sebanya 51 (lima puluh satu) kasus/perkara perikanan yang masuk ke Pengadilan Negeri Tanjung pinang. 


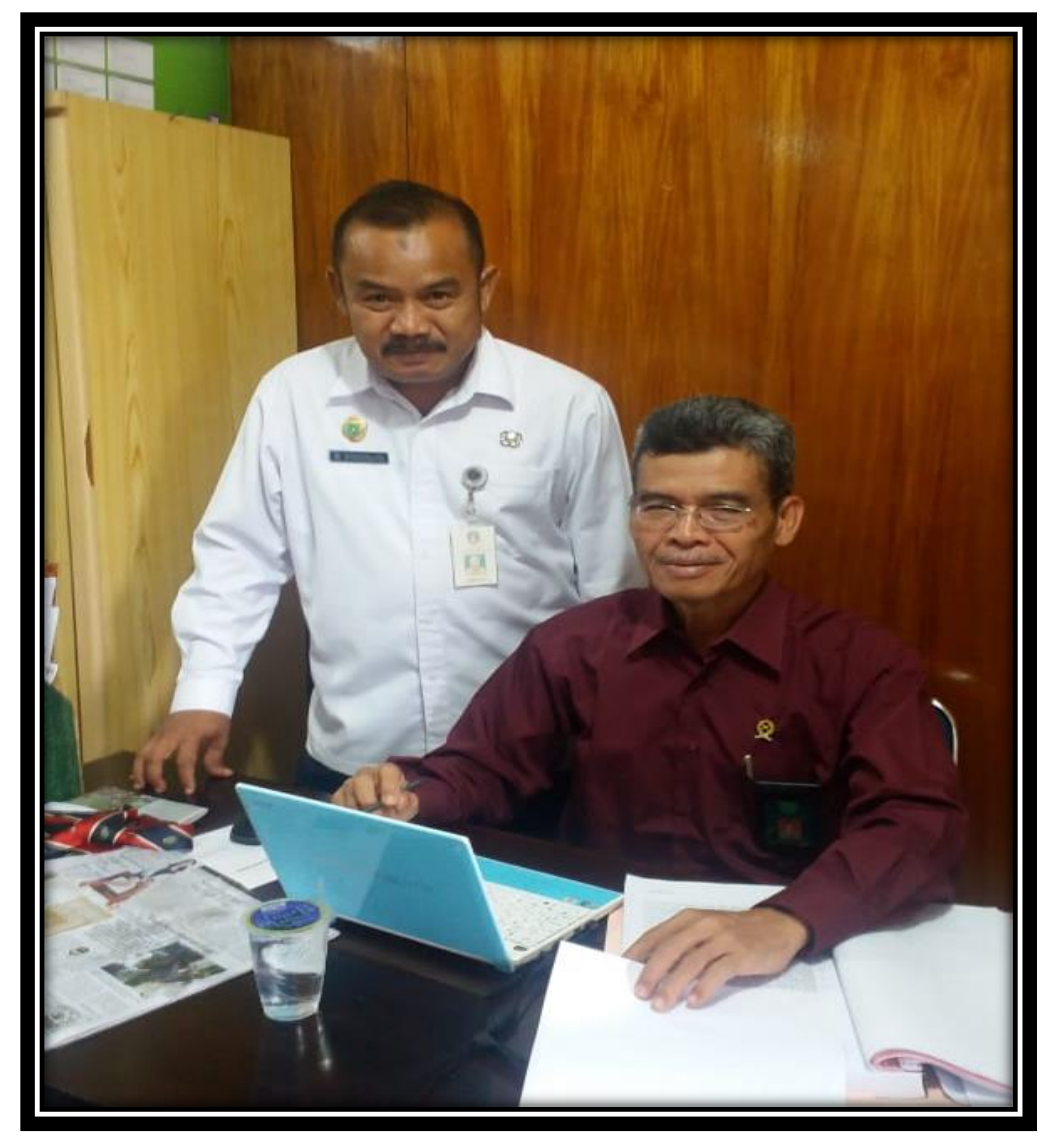

\section{Gambar 3 hasil wawancara dengan Hakim Perikanan pada Pengadilan Negeri Tanjung Pinang}

Peneliti juga melakukan wawancara pada Bapak Ir. Syafriyulis, MM sebagai Hakim Pengadilan Perikanan pada Pengadilan Negeri Tanjungpinang, hasil wawancara yang dilakukan pada bulan September 2018 ini, beliau berpendapat bahwa kasus pencurian ikan di daerah Provinsi Kepulauan Riau tiap tahunya bervariasi, mulai tahun 2010 sampai tahun 2018, pelanggaran pencurian ikan tertinggi terjadi pada tahun 2017 yaitu sebanya 51 (lima puluh satu) kasus/perkara perikanan yang masuk ke Pengadilan Negeri Tanjungpinang. Sejauh ini pada prinsipnya`Pengadilan Negeri hanya menerima perkara yang dilimpahkan oleh penuntut umum, memeriksa, menyidangkan dan segera memutus perkara sesuai dengan kesalahan pelanggaran yang dilakukan oleh terdakwa sesuai dengan ketentuan undang-undang perikanan yang berlaku. Kewenangan Pengadilan Perikanan pada Pengadilan Negeri Tanjungpinang adalah menerima perkara yang dilimpahkan oleh penuntut umum, memeriksa, menyidangkan dan segera memutus perkara tersebut sampai mempunyai status hukum yang tetap inkrah jika tidak banding, dan jika ada upaya banding bisa diputus ditingkat banding atau sampai kasasi. 
Menurut Bapak Syafriyulis instansi yang terkait dalam penanganan pencurian ikan adalah TNI Angkatan Laut, Polairud dan Pengawasan Sumber daya Kelautan dan Perikanan (PSDKP). Pengadilan perikanan menggunaan acuan hukum yaitu Undangundang nomor 45 tahun 2009 tentang perubahan Undang-Undang Nomor 31 Tahun 2004 tentang Perikanan, dan hambatan yang ditemukan dalam melaksanakan tugas adalah sering molornya rencana tuntutan dari Jaksa Penuntut Umum serta keterbatasan penerjemah dalam menyelesaikan kasus pencurian ikan negara lain, seperti Vietnam dan lain-lain.

Dari hasil wawancara tersebut juga didapatkan dapat bahwa sepanjang tahun 2016 Pengadilan Perikanan pada Pengadilan Negeri Tanjungpinang terdapat 30 kasus, tahun 2017 terdapat 51 kasus dan tahun 2018 pertanggal 10 September terdapat 20 kasus. Untuk menyelesaikan kasus-kasus`tersebut Pengadilan Perikanan pada Pengadilan Negeri Tanjungpinang terus berkoordinasi dengan pihak pihak terkait dan koordinasi berjalan dengan`baik, tidak ada kendala yang berarti dan dan serius, serta solusi supaya penuntun umum retut (rencana tuntutan) tepat waktu dan untuk penerjemah bahasa semoga dapat disiapkan sebelum persidangan.

Contoh kasus yang pernah ditangani oleh Pengadilan Perikanan pada Pengadilan Negeri Tanjungpinang yaitu tahun 2016 dengan Nomor Perkara 1/pid.susPRK/2016/PN. TPG. An. Sumarno. Tahun 2017 dengan Nomor Perkara 2/pid.susPRK/2017/PN. TPG. An. Andi Wiliam dan Tahun 2018 dengan Nomor Perkara 3/pid.sus-PRK/2016/PN. TPG. An. Restu Kurniawan.

\section{Kasus Pencurian Ikan di Wilayah Perbatasan Kepulauan Riau} Putusan Nomor : 12/Pid.Sus.Prkn/2016/PN.TPg

Pengadilan Perikanan pada Pengadilan Negeri Tanjungpinang yang memeriksa dan mengadili perkara pidana perikanan pada peradilan tingkat pertama dengan acara pemeriksaan biasa, menjatuhkan putusan dalam perkara terdakwa :

$\begin{array}{ll}\text { Nama } & : \text { HTEIN LIN AUNG } \\ \text { Tempat lahir } & : \text { Esing (Myanmar) } \\ \text { Umur tanggal lahir } & : \text { 35 Tahun/18 Juli 1981 } \\ \text { Jenis kelamin } & \text { :Laki-laki. } \\ \text { Kebangsaan } & \text { :Myanmar } \\ \text { Tempat tinggal } & \text { :Asin Village, Ye Towship, Mon State, } \\ \text { Myanmar. } & \\ \text { Agama } & \text { : Budha } \\ \text { Pekerjaan } & : \text { Nahkoda KM.KHF } 1917\end{array}$

Terdakwa ditahan dengan jenis penahanan Rumah Tahan Negara (Rutan) berdasarkan Surat Perintah/Penetapan Penahanan dari:

1. Penyidik, sejak tanggal 08 Maret 2016 s/d 27 Maret 2016.

2. Perpanjangan Penahanan oleh Penuntut Umum, sejak tanggal 28 Maret 2016 s/d tanggal 06 Maret 2016. 
3. Penuntut Umum, sejak tanggal 06 April 2016 s/d tanggal 15 April 2016.

4. Hakim Pengadilan Negeri Tanjung Pinang; Nomor: 12/Pen.Pid.Sus-PRK/ 2016 /PN.TPg, tanggal 13 April 2016, sejak tanggal 13 April 2016 s/d tanggal 2 Mei 2016.

5. Perpanjangan Penahanan, Wakil Ketua Pengadilan Tanjungpinang Nomor.12/ Pen.Pid.Sus-PRK/2016/PN.TPg, tanggal 25 April 2016, terhitung sejak tanggal 3 Mei 2016 s/d tanggal 12 Mei 2016.

Terdakwa dalam perkara ini tidak didampingi Penasihat Hukum meskipun hak untuk itu telah diberikan kepadanya;Terdakwa dalam perkara ini didampingi juru bahasa (penterjemah) bahasa Myanmar ke dalam bahasa Indonesia dan sebalinya.

Pengadilan Perikanan pada Pengadilan Negeri Tanjungpinang;

Menimbang, bahwa sesuai fakta-fakta yang terungkap di persidangan, Majelis Hakim akan mempertimbangkan dakwaan Penuntut Umum Pasal 85 jo Pasal 9 ayat (1) jo Pasal 5 ayat (1) huruf a Undang-Undang Nomor 45 Tahun 2009 tentang perubahan atas Undang-Undang Nomor 31 Tahun 2004 tentang Perikanan, dimana unsur-unsur pokoknya adalah sebagai berikut :

1. Setiap orang.

2. Dengan sengaja memiliki, menguasai, membawa, dan/atau menggunakan alat penangkap ikan dan/atau alat bantu penangkap ikan mengganggu dan merusak keberlanjutan sumber daya ikan, dikapal penangkap ikan.

3. Di Wilayah Pengelolaan Perikanan Republik Indonesia (WPPRI).

\section{Unsur Setiap Orang.}

Menimbang, bahwa menurut ketentuan Pasal 1 angka 14 UU Nomor 45 Tahun 2009 tentang Perubahan atas UU Nomor 31 Tahun 2004 tentang Perikanan, yang dimaksud dengan setiap orang adalah orang perorangan atau korporasi. Berdasarkan ketentuan tersebut maka yang dimaksud setiap orang yaitu siapa saja selaku subjek hukum yang dapat mempertanggungjawabkan perbuatannya, baik Warga Negara Indonesia maupun Warga Negara Asing, Badan Hukum Indonesia maupun badan hukum Asing yang melakukan kegiatan perikanan di Wilayah Republik Indonesia, in casu Terdakwa HTEIN LIN AUNG .

Menimbang, bahwa dalam perkara ini telah dihadapkan ke persidangan Terdakwa Htein Lin Aung adalah warganegara Myanmar selaku Nahkoda Kapal Ikan KM.KHF.1917, dalam keadaan sehat jasmani dan rohani serta mampu menjawab seluruh pertanyaan yang diajukan kepadanya dengan jelas dan tanggap serta selama pemeriksaan perkara ini berlangsung, Majelis Hakim tidak melihat adanya hal-hal yang dapat menghapus kesalahannya, sehingga Terdakwa dipandang sebagai orang yang mampu mempertanggung jawabkan perbuatannya yang telah didakwakan dalam perkara ini. 
Menimbang, bahwa berdasarkan fakta-fakta di persidangan maka benar Terdakwa sebagai subjek hukum yang identitasnya telah dicocokkan sebagaimana diuraikan dalam dakwaan Jaksa Penuntut Umum yang dibenarkan pula oleh Terdakwa sendiri.

Menimbang, bahwa dengan demikian unsur "setiap orang" telah terpenuhi menurut hukum.

\section{Unsur di Wilayah Pengelolaan Perikanan Republik Indonesia.}

Menimbang, bahwa yang dimaksud dengan Wilayah Pengelolahan Perikanan Republik Indonesia (WPPI) adalah untuk melakukan penangkapan ikan dan/atau pembudidayaan ikan dalam Pasal 5 ayat (1) huruf a Undang-Undang Nomor. 31 Th 2004 tentang Perubahan atas Undang-Undang Nomor. 45 Tahun 2009 tentang Perikanan, salah satunya adalah meliputi: a) Perairan Indonesia.

Menimbang bahwa yang dimaksud Perairan Indonesia (Pasal 5 ayat (1) huruf a) adalah Laut Teritorial Indonesia beserta perairan Kepulauan dan perairan pedalaman (Pasal 1 angka 20), menurut Undang-Undang Nomor.45 Tahun 2004 tentang perubahan atas Undang-Undang Nomor. 31 Tahun 2004 tentang Perikanan.

Menimbang, bahwa selanjutnya yang dimaksud dengan laut teritorial, adalah jalur laut selebar 12 (dua belas) mil laut yang diukur dari garis pangkal Kepulauan Indonesia (Pasal 1 angka 19), menurut Undang-Undang Nomor.45 Tahun 2004 tentang perubahan atas Undang-Undang Nomor. 31 Tahun 2004 tentang Perikanan.

Menimbang, berdasarkan keterangan saksi-saksI ABK Kapal Motor KM.KHF 1917 dan Saksi Kapal Pengawas KP.HIU.15 Kapal Patroli Penangkap yaitu: Japarudin Lalla, A.Md, Novein Ernest Brando Repi, A.Md dan keterangan terdakwa Htein Lin Aung sendiri telah menerangkan selama beroperasi di perairan laut teritorial Indonesia yang merupakan Wilayah Pengelolaan Perikanan Republik Indonesia (WPPRI) terdakwa dalam melakukan kegiatan penangkapan ikan telah mendapatkan ikan campuran sekitar $\pm 100 \mathrm{Kg}$ (lebih kurang seratus kilogram).

Menimbang, bahwa diperoleh fakta-fakta di persidangan terdakwa Htein Lin Aung dengan menggunakan Kapal Motor KM.KHF 1917, telah ditangkap oleh Patroli Kapal Pengawas KP.Hiu 15, pada hari Kamis tanggal 03 Maret 2016 sekira pukul 06.20 WIB atau setidak-tidaknya dalam bulan Maret tahun 2016, bertempat di Wilayah Pengelolaan Perikanan Republik Indonesia Perairan Laut Teritorial Indonesia (Selat Malaka) pada posisi $02^{\circ} 57,795^{\prime} \mathrm{LU}-100^{\circ} 49,523^{\prime} \mathrm{BT}$

Menimbang, bahwa selanjutnya pada posisi koordinat $02^{\circ} 57,795^{\prime}$ LU- $100^{\circ}$ 49,523' BT; Perairan Teritorial Indonesia yang merupakan Wilayah Pengelolaan Perikanan Republik Indonesia.

Menimbang, bahwa berdasarkan pertimbangan di atas Majelis Hakim berpendapat, Unsur-unsur di Wilayah Pengelolahan Perikanan Republik Indonesia telah terpenuhi menurut hukum.

Menimbang, bahwa menurut Majelis Hakim oleh karena dakwaan penuntut umum alternatif ketiga telah memenuhi unsur sebagaimana diatur dalam Pasal 85 Jo Pasal 9 
(1) Jo Pasal 5 ayat (1) huruf a Undang-Undang Nomor. 45 Tahun 2009 Tentang Perubahan atas Perikanan Undang-Undang No.31 Tahun 2004 Tentang Perikanan.

Menimbang, bahwa oleh karena itu dakwaan penuntut umum sesuai dengan uraian di atas telah memenuhi unsur, maka Majelis Hakim berpendapat dakwaan Penuntut Umum kepada terdakwa Htein Lin Aung terbukti bersalah melanggar sebagaimana yang diatur dan diancam pada Pasal 85 Jo Pasal 9 (1) jo Pasal 5 ayat (1) huruf a Undang-Undang Republik Indonesia Nomor 45 Tahun 2009 tentang perubahan atas Undang-Undang Republik Indonesia Nomor 31 Tahun 2004 Tentang Perikanan.

Menimbang, bahwa selanjutnya dipersidangan, Majelis Hakim tidak menemukan adanya alasan pembenar maupun alasan pemaaf yang dapat menghapus sifat melawan hukum perbuatan yang dilakukan Terdakwa, maka Terdakwa patut dijatuhi pidana.

Menimbang, bahwa oleh karena Terdakwa mampu bertanggung jawab, maka Terdakwa harus dinyatakan bersalah atas tindak pidana yang didakwakan terhadap diri Terdakwa, oleh karena itu harus dijatuhi pidana.

Menimbang, bahwa Terdakwa ditahan berdasarkan undang-undang, maka penahanan Terdakwa tersebut sah menurut hukum, sehingga sesuai dengan ketentuan Pasal 22 ayat (4) KUHAP, maka Majelis menetapkan agar hukuman yang akan dijalankan oleh Terdakwa tersebut akan dikurangkan seluruhnya dengan masa penahanan yang telah dijalani oleh Terdakwa.

Menimbang, bahwa oleh karena Terdakwa ditahan sesuai dengan ketentuan Pasal 197 ayat (1) huruf k KUHAP penahanan terhadap diri Terdakwa adalah sah,Terdakwa tetap berada dalam tahanan.

Menimbang, bahwa barang bukti berupa 1 (satu) unit kapal KM.KHF 1917, yang digunakan untuk melakukan kejahatan dibidang Perikanan, sudah dimusnahkan berdasarkan surat perintah Kepala Satker PSDKP Batam Nomor: SP.Musnah.22.K/PPNS-Kan/BTM-Sta.2/PP/520/III/2016 dan/atau Penetapan Penyitaan dari Ketua Pengadilan Negeri Batam Nomor. 261/Pen.Pid/2016/PN. BTM, tanggal 15 Maret 2016.

Menimbang, bahwa barang bukti berupa 1 (satu) set alat penangkap ikan Jaring Trawl (Pukat Harimau) merupakan alat tangkap ikan yang dilarang penggunaannya di Indonesia, menurut Majelis Hakim harus dimusnahkan.

Menimbang, bahwa barang bukti ikan campuran hasil tangkapan sebanyak \pm 100 Kg (lebih kurang seratus kilogram) sudah dimusnahkan berdasarkan berita acara pemusnahan tanggal 11 Maret 2016, dan Penetapan pemusnahan oleh Ketua Pengadilan Negeri Batam Nomor.17/Pen.Pid/ 2016/ PN.BTM, tanggal 23 Maret 2016.

Menimbang, bahwa ikan campuran sebanyak $\pm 100 \mathrm{Kg}$ (lebih kurang seratus kilogram) yang sudah membusuk dan tidak layak untuk dikonsumsi segera dimusnakan.

Menimbang, bahwa barang bukti berupa: 1 (Satu) Unit alat Navigasi GPS Plotter/Sounder MMEC-APS 832mk2, 1 (Satu) Unit Kompas Magnet Tokyo Compass, 1 (Satu) unit Radio Virage, 1 (Satu) Unit alat komunikasi alat komunikasi Radar JMC V3300P, 1 (Satu) buah buku dokumen lessen Vessel dimusnahkan. 
Menimbang, bahwa dalam pasal yang didakwaan terbukti selain hukuman penjara kepada terdakwa juga dihukum membayar denda yang besarnya akan dipertimbangkan dalam amar putusan.

Menimbang, bahwa oleh karena Terdakwa dijatuhi pidana dan Terdakwa sebelumnya tidak mengajukan permohonan pembebasan dari pembayaran biaya perkara, maka Terdakwa harus dibebankan untuk membayar biaya perkara sebagaimana diatur Pasal 222 KUHAP yang besarnya akan ditentukan dalam amar putusan ini.

Menimbang, bahwa sebelum menjatuhkan Putusan, Majelis Hakim akan mempertimbangkan hal-hal yang memberatkan dan meringankan sebagaimana terurai di bawah ini :

Hal-hal yang memberatkan:

1. Potensi Sumber Daya Ikan berkurang, pendapat Negara dari sumber kelautan juga berkurang;

2. Dampak penggunaan alat tangkap jaring trawl merusak keberlanjutan sumber daya alam didalam didalam laut;

Hal-hal yang meringankan:

1. Terdakwa tulang punggung keluarga;

2. Terdakwa belum pernah dihukum;

Mengingat Pasal 85 Jo Pasal 9 ayat (1) Undang-Undang No. 45 Tahun 2009 jo Pasal 5 (1) huruf a, Tentang Perubahan atas Undang-Undang No. 31 Tahun 2004 Tentang Perikanan; Undang-Undang No. 8 Tahun 1981 serta peraturan-peraturan lain yang berkaitan dengan perkara ini;

\section{MENGADILI}

1. Menyatakan Terdakwa HTEIN LIN AUNG telah terbukti secara sah dan meyakinkan bersalah melakukan tindak pidana Perikanan "Dengan sengaja menggunakan alat penangkap ikan yang menggangu dan merusak keberlanjutan sumber daya ikan di kapal penangkap ikan, di Wilayah Pengelolaan Perikanan Republik Indonesia”.

2. Menjatuhkan pidana kepada Terdakwa Htein Lin Aung oleh karena itu dengan pidana penjara selama 2 (dua) tahun dan denda sebesar Rp 1.500.000.000,-(satu milyart lima ratus juta rupiah), dengan ketentuan apabila denda tidak dibayar, maka diganti dengan pidana kurungan selama 4 (empat) bulan;

3. Menetapkan lamanya masa penahanan yang telah dijalani oleh Terdakwa dikurangkan seluruhnya dari Pidana yang dijatuhkan;

4. Menetapkan Terdakwa tetap berada dalam tahanan;

5. Menetapkan barang bukti dalam perkara ini berupa:

- 1 ( satu ) unit Kapal KM. KHF 1917 
- $\pm 100 \mathrm{Kg}$ (lebih kurang seratus kilogram) ikan campur, sudah dimusnahkan berdasarkan Penetapan Ketua Pengadilan Negeri Batam Nomor. Nomor.17/Pen.Pid/2016/PN.BTM, tanggal 23 Maret 2016 ;

- 1 (satu) Unit alat tangkap jaringTrawl;

- 1 (satu) Unit alat Navigasi GPS Plotter/Sounder MMEC-APS 832mk2

- 1 (satu) Unit alat komunikasi Radar JMC V-3300P;

- 1 (satu) unit Kompas Magnet Tokyo Compass;

- 1 (satu) buah buku dokumen lessen vessel dan peralatan penangkap ikan;

\section{Dimusnahkan.}

6. Membebankan kepada Terdakwa untuk membayar biaya perkara sebesar Rp 5.000,- (lima ribu rupiah).

Demikianlah diputuskan dalam Rapat Permusyawaratan Majelis Hakim Pengadilan Perikanan pada Pengadilan Negeri Tanjungpinang pada hari: Rabu tanggal 11 Mei 2016oleh kami Jhonson Fredy Esron Sirait, SH. Ketua Majelis Hakim, Drs. Ichsan Suwanto, MM Dan H. Agus Susanto DPN, SH., MH. masing-masing Hakim Ad Hoc sebagai Hakim Anggota Majelis, Putusan mana pada hari: Rabu tanggal 11 Mei 2016, diucapkan dalam persidangan terbuka untuk umum oleh Hakim Ketua Majelis dengan didampingi oleh Hakim Ad Hoc sebagai Hakim-Hakim Anggota Majelis dan dibantu oleh Thomas Aidi Pandia, Panitera Pengganti Pengadilan Perikanan pada Pengadilan Negeri Tanjung Pinang serta dihadiri oleh Andi Akbar,SH., Jaksa Penuntut Umum pada Kejaksaan Negeri Batam dan Terdakwa dengan didampingi Penterjemah.

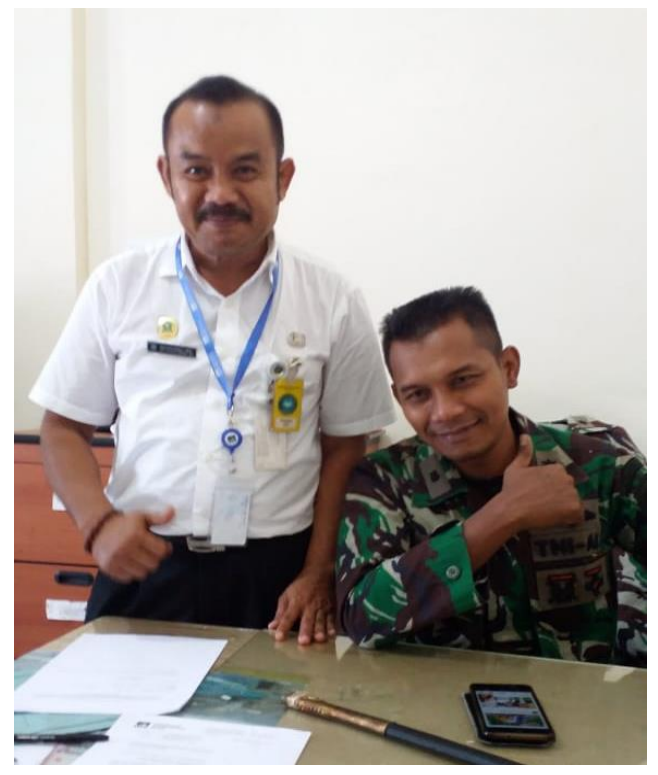

Gambar 4 hasil wawancara Dengan Pangkalan IV TNI Angkatan Laut Tanjungpinang 
Hasil wawancara yang peneliti lakukan pada Dinas Hukum Lantamal IV yaitu Bapak Mayor, Bambang Sulistyono, SH yaitu beliau berpendapat bahwa kasus pencurian ikan atau pencurian ikan dilakukan oleh nelayan asing yang tidak dilengkapi SIPI dan izin lainya dan melanggar peraturan perundang-undangan yang berlaku di negara Indonesia. Dan dalam hal ini angkatan Laut melakukan tindakan tegas sesuai dengan amanah undang-undang bahwa kewenangan TNI Angkatan Laut adalah sebagai penyidik dalam kasus pencurian ikan. Selain TNI Angkatan Laut, instansi lain yang diamanatkan oleh undang undang untuk menangani kasus pencurian ikan adalah PSDKP, Polisi Airud yang dalam prosesnya mengacu pada Undang-undang Tindak Pidana Perikanan. Dan kewenangan TNI Angkatan Laut sesuai dengan amanat undangundang sesuai dengan fungsi penyidik, penyelidik terhadap tindak pidana pencurian ikan di wilayah hukum TNI Angkatan Laut Lantamal IV Tanjungpinang.

Dasar hukum yang menjadi acuan penanganan kasus pencurian ikan yang digunakan oleh TNI Angkatan Laut adalah KUHAP pasal 6 yang menjelaskan penyidik adalah Pejabat Tentara Republik Indonesia angkatan laut dan Undang-undang Nomor 45 tahun 2009 tentang perubahan Undang-undang Nomor 31 Tahun 2004 tentang Perikanan. Dalam menjalankan tuganya TNI Angkatan Laut sering kali mendapat hambatan yaitu luasnya wilayah laut Provinsi Kepri yaitu 95,5 \%, keterbatasan sarana dan prasarana, serta kondisi cuaca dan personil yang terbatas. Terkait kasus sepanjang tahun 2016. 2017 dan 2018, tedapat 74 kasus yaitu 21 kasus di tahun 2016, 42 kasus ditahun 2017 dan 11 kasus ditahun 2018 pertanggal 18 September. Untuk menyelesaikan kasus kasus tersebut TNI Angkatan Laut berkoordinasi dengan baik sampai pada pelimpahan berkas perkara tindak pidana perikanan ke jaksa penuntut umum.

\section{Pembahasan}

\section{Instansi yang mempunyai kewenangan dalam hal terjadinya kasus pencurian ikan di wilayah perbatasan Provinsi Kepulauan Riau}

Peraktik pencurian ikan merupakan satu dari sekian banyak kasus hukum yang terjadi di di daerah perbatasan khususnya Provinsi Kepulauan Riau. Penegakan hukum merupakan salah satu prasyarat untuk mengantar Indonesia sebagai poros maritim dunia. Berbicara penegakan hukum, hal ini masih merupakan pekerjaan rumah yang berat bagi pemerintah. Wilayah perairan Indonesia yang mencapai $72.5 \%$ dan luas laut Provinsi Kepulauan Riau seluas 95,5 \% memberi tantangan besar bagi TNI AL, Polisi Air, dan instansi terkait untuk memastikan kemanan dan perlindungan terhadap yurisdiksi Indonesia dan Kepulauan Riau pada khususnya. Praktik Pencurian ikan merupakan satu dari sekian pelanggaran yang paling masif dilakukan di wilayah perairan Indonesia. Pencurian ikan dilakukan oleh kapal ikan asing yang secara illegal masuk ke dalam wilayah perairan Indonesia, dan melakukan penangkapan ikan tanpa mengantongi izin dari pemerintah. Praktik ini jelas telah sangat merugikan negara setiap tahunnya, bahkan menurut Menteri Kelautan dan Perikanan Susi 
Pudjiastuti kerugian negara mencapai Rp 240 triliun. Tidak hanya itu, praktik pencurian ikan juga menyebabkan kerugian lainnya, yakni kerusakan ekosistem laut. Data dari Pusat Penelitian Oseanografi Lembaga Ilmu Pengetahuan Indonesia (LIPI) mengungkap data mengejutkan mengenai kondisi terumbu karang, dimana hanya 5,3\% terumbu karang Indonesia yang tergolong sangat baik, sementara 27,18\%-nya digolongkan dalam kondisi baik, 37,25\% dalam kondisi cukup, dan $30,45 \%$ berada dalam kondisi buruk, dimana kerusakan terumbu karang ini sebagian besar disebabkan oleh praktik pencurian ikan yang menggunakan sianida dan alat tangkap terlarang.

Ini menimbulkan masalah serius, karena terumbu karang adalah rumah bagi ikan, dan jika kita berlogika secara sederhana saja, keruskan terumbu karang artinya kerusakan terhadap kehidupan ikan itu sendiri. Tentu hal tersebut adalah berita buruk bagi sekitar 2,2 juta nelayan di seluruh Indonesia. Yang dipastikan akan kehilangan mata pencahariannya Dapat dilihat bahwa praktik pencurian ikan, yang oleh masyarakat internasional telah diklasifikasikan sebagai transnational and organized crime, dipastikan akan menciptakan sederetan masalah jika kondisi buruk ini tidak segera diselesaikan. Pemerintah, sebenarnya bukan tanpa tindakan. Pasal 69 ayat (4) dalam Undang-undang No 45 Tahun 2009 tentang Perikanan memiliki serangkaian payung hukum terkait penegakan hukum terhadap tindakan pencurian ikan, salah satunya adalah dimungkinkannya dilakukan penenggelaman kapal yang terbukti melakukan pengangkapan ikan tanpa izin. Berdasarkan Undang-undang Nomor 45 Tahun 2009 tentang Perikanan, dijelaskan bahwa Perikanan adalah semua kegiatan yang berhubungan dengan pengelolaan dan pemanfaatan sumber daya ikan dan lingkungannya mulai dari praproduksi, produksi, pengolahan sampai dengan pemasaran yang dilaksanakan dalam suatu sistem bisnis perikanan.12 Terlihat bahwa rangkain kegiatan mulai dari pengelolaan sampai pemasaran ikan merupakan satu kesatuan yang tidak dipisahkan dan diatur oleh undang-undang tersebut. Perkembangannya sekarang dengan prinsip otonomi daerah dimana daerah memiliki kewenangan yang cukup luas untuk mengelolah daerahnya meliputi laut, khususnya daerah-daerah kepulauan. Berdasarkan Undang-undang Nomor 23 Tahun 2014 tentang Pemerintahan Daerah, khususnya Provinsi mempunyai kewenangan yang cukup besar. Hal tersebut dijelaskan dalam Pasal 27 UU No. 23 Tahun 2014 tentang Pemerintahan Daerah, dalam undang-undang tersebut dijelaskan bahwa:

Daerah provinsi diberi kewenangan untuk mengelola sumber daya alam di laut yang di wilayahnya;

1) Kewenangan Daerah provinsi untuk mengelola sumber daya alam di laut sebagaimana dimaksud pada ayat (1) meliputi:

a) eksplorasi, eksploitasi, konservasi, dan pengelolaan kekayaan laut di luar minyak dan gas bumi;

b) pengaturan administratif;

c) pengaturan tata ruang;

d) ikut serta dalam memelihara keamanan di laut; dan 
e) ikut serta dalam mempertahankan kedaulatan negara.

2) Kewenangan Daerah provinsi untuk mengelola sumber daya alam di laut sebagaimana dimaksud pada ayat (1) paling jauh 12 (dua belas) mil laut diukur dari garis pantai ke arah laut lepas dan/atau ke arah perairan kepulauan.

3) Apabila wilayah laut antar dua Daerah provinsi kurang dari 24 (dua puluh empat) mil, kewenangan untuk mengelola sumber daya alam di laut dibagi sama jarak atau diukur sesuai dengan prinsip garis tengah dari wilayah antardua Daerah provinsi tersebut.

4) Ketentuan sebagaimana dimaksud pada ayat (3) dan ayat (4) tidak berlakuterhadap penangkapan ikan oleh nelayan kecil.

Posisi geografis Indonesia yang strategis, banyak pihak-pihak tertentu yang melakukan kegiatan di wilayah maritim Indonesia yang melanggar ketentuan peraturan perundang-undangan baik secara nasional, maupun internasional yang dapat digolongkan dalam bentuk ancaman sebagai berikut: ${ }^{12}$

a. Ancaman kekerasan (violence threat); yaitu ancaman dengan menggunakan kekuatan bersenjata terorganisir, antara lain: pembajakan, perampokan, aksi teror, sabotase;

b. Ancaman terhadap sumber daya laut (natural resources tribulation); berupa pencemaran dan pengrusakan terhadap ekosistem laut dan konflik pengelolaan sumber daya laut yang dipolitisasi dan diikuti dengan pergelaran kekuatan militer;

c. Ancaman pelanggaran hukum (low transgression threat); yaitu tidak dipatuhinya hukum nasional maupun internasional yangberlaku di perairan, antara lain illegal logging, pencurian ikan, penyeludupan;

d. Ancaman navigasi (navigational hazard); yaitu ancaman yang timbul oleh kondisi geografis maritim dan hidrografi akibat kurang memadainya sarana bantu navigasi sehingga dapat membahayakan keselamatan pelayaran.

Berdasarkan sebagaimana diuraikan di atas khususnya pada poin c, yaitu ancaman pelanggaran hukum yaitu tidak dipatuhinya berbagai ketentuan yang mengatur diperairan khususnya penangkapan ikan yang dilakukan secara ilegal (pencurian ikan) di wilayah laut Provinsi Kepulauan Riau. Berbagai kasus sudah banyak terjadi, baik yang dilakukan oleh oknum warga negara Indonesia sendiri maupun warga negara lainnya. Hal ini sangat memprihatinkan karena dengan memilki laut yang begitu luas yang di dalamnya berbagai jenis ikan merupakan potensi sumber daya alam yang luar biasa yang dimiliki oleh Kepulauan Riau. Maraknya kejahatan pencurian ikan mengancaman konservasi ikan dan juga sekaligus mengancam kedaulatan negara. Berbagai laporan dari masyarakat antara lain, masyarakat nelayan setempat takut melaut karena diganggu, diserang bahkan ditabrak kapalnya oleh nelayan asing yang memiliki alat penangkapan atau kapal yang lebih baik. Dengan tindakan para nelayan asing tersebut yang menakut-nakuti nelayan setempat, mereka cukup leluasa

\footnotetext{
${ }^{12}$ Tanpa nama, Penataan Pengamanan Wilayah Maritim Guna Memelihara Stabilitas dalam RangkaMenjaga Kedaultan NKRI, Jurnal Kajian Lemhanas RI, Edisi 14, Desember 2012, hlm. 75
} 
melakukan praktik lllegal Fishing di wilayah Kepulauan Riau, seperti perairan Anambas dan Natuna.

Dari hasil penelitian lapangan yang peneliti lakukan dari hasil wawancara yang peneliti lakukan pada pihak Polisi Air Polda Kepri, Dinas Kelautan dan Perikanan, Pengadilan Perikanan Pada Pengadilan Negeri Tanjungpinang dan TNI Angkatan Laut Lantamal IV Tanjungpinang peneliti mendapatkan jawaban bahwa instansi atau lembaga yang berwenang dan saling berkoordinasi dalam kasus terjadinya pencurian ikan di wilayah Kepulauan Riau adalah:

1. TNI Angkatan Laut

2. Polisi Air Polda Kepri

3. Dinas Kelautan dan Perikanan Provinsi Kepulauan Riau

4. Pengadilan Pengadilan Negeri

5. Kejaksaan Negeri

6. Direktorat Jenderal Pengawasan Sumber daya Kelautan dan Perikanan

Sesuai dengan amanat undang-undang Nomor 45 Tahun 2009 tentang Perikanan, masing-masing lembaga tersebut saling berkoordinasi dengan baik dalam menyelesaikan dan menindak kasus-kasus pencurian ikan yang terjadi di Provinsi Kepulauan Riau.Penanggulangan kejahatan Pencurian ikan di Kepulauan Riau dilakukan dengan sarana penal. Sarana penal lebih tepatnya penanggulangan Pencurian ikan lewat jalur litigasi, mulai dari penangkapan, penahanan, penuntutan, persidangan di pengadilan dan eksekusi terhadap kasus-kasus Pencurian ikan. Umumnya instansi yang terkait dalam penananganan suatu kasus antara lain kepolisian, kejaksaan dan pengadilan. Namun penegakan hukum dilaut tidak hanya melibatkan kepolisian, kejaksaan dan pengadilan saja, ada juga Kementerian Kelautan dan Perikanan, Badan Keamanan Laut, Bea Cukai, Dinas Perhubungan, serta Satgas pencurian ikan. Selain ini juga menggunakan sarana non penal. Non penal pada prinsipnya adalah penanganan suatu kasus tertentu dilaur hukum pidana. Sudarto mengartikan hukum pidana bahwa memuat aturan-aturan hukum yang mengikatkan kepada perbuatan-perbuatan yang memenuhi syarat tertentu suatu akibat yang berupa pidana. ${ }^{13}$ Prinsip dasar dalam hukum pidana bahwa suatu sanksi yang berupa pidana itu merupakan sarana terakhir dalam menanggulangi kejahatan. Apabila dimungkinkan saranasarana lain seperti sanksi adminsitrasi atau sanski perdata bisa menyelesaiakan dan memulihkan keadaan akan lebih baik dari pada langsung menggunakan sanksi pidana.

Sarana penal dengan menjatuhkan sanksi pidana berupa pidana penjara dan denda yang berpariatif, serta tindakan penenggelaman kapal. Aparat penegakan hukum Pencurian ikan meliputi DKP, Dishub, TNI AL, Polri, Kejagung, Bakamla, Satgas Pencurian ikan. Daerah yang sering terjadi Pencurian ikan di Kepulauan Riau meliputi perairan Anambas dan Natuna. Sedangkan upaya non penal dapat dilakukan dengan peningkatan patroli, kerjasama antar negara, meningkatkan teknologi informasi pengawasan, serta melibatkan LSM dan masyarakat setempat untuk memberikan informasi tentang adanya Pencurian ikan. Sebagaimana hasil penelitian dari dua kasus

${ }^{13}$ Sudarto, Hukum dan Hukum Pidana, Alumni, Bandung,2007, hlm. 92 
yang telah diputus oleh Pengadilan Negeri Tanjungpinang peneliti dapatkan dari hasil penelitian bahwa setiap orang yang melakukan pencurian ikan akan dilakukan proses pemeriksaan oleh instansi berwenang, yaitu TNI Angkatan Laut dan Polisi Air, dalam hal penangkapan dan pemeriksaan dan dalam hal penuntutan dilaksanakan oleh kejaksaan dan pengadilan perikanan pengadilan negeri Tanjung pinang yang mengadili dan memberikan putusan terhadap kasus pencurian ikan tersebut. Dari proses tersebut sesuai dengan teori perlindungan hukum dimana segala proses tersebut sampai dengan dijatuhkannya putusan adalah untuk memberikan perlindungan hukum kepada masyarakat dimana, hasil laut menjadi milik negara dan masyarakat dapat menggunakannya sesuai dengan ketentuan peraturan perundang-undangan hukum yang berlaku. Ketika semua terlindungi maka pembangunan bangsa akan bergerak dengan baik sesuai dengan Teori Hukum Pembangangunan Mochtar Kusumaatmadja bahwa pola kerja hukum pembangunan adalah dengan melibatkan seluruh stakeholders yang ada dalam komunitas sosial termasuklah di dalamnya masyarakat dan intstansi berwenang dalam menyelesaikan kasus pencurian ikan di wilayah perbatasan provinsi Kepulauan Riau.

\section{Tindakan yang dilakukan oleh instansi berwenang dalam penegakan hukum terhadap pihak yang melakukan pencurian ikan di wilayah perbatasan Provinsi Kepulauan Riau}

Berbicara tentang peran dan kewenangan masing-masing instansi dalam penanganan kasus pencurian ikan atau pencurian ikan, maka kewenangan tersebut dibagi atas dasar wilayah pencurian ikan dilakukan oleh pencuri, pelaku pencurian ikan ini bisa kapal lokal atau kapal asing. Sesuai dengan UNCLOS 1982 membagi laut dalam tiga bagian yaitu laut teritorial, laut yang merupakan wilayah kedaulatan suatu negara, kedua laut yang bukan kedaulatan suatu wilayah negara namun negara tersebut mempunyai hak-hak dan yurisdiksi terhadap aktifitas tertentu yaitu zona tambahan zona eksklusif tertentu, dan yang ketiga adalah laut yang bukan kedaulatanya dan bukan merupakan hak yurisdiksi namun negara tersebut memiliki kebebasan atau disebut dengan laut bebas. Maka kewenangan masing-masing instansi dalam menangani kasus pencurian ikan di wilayah Kepulauan Riau juga mengikuti aturan tersebut, kewenangan terkait tempat dilakukanya pencurian ikan itu terjadi.

Polisi air mempunyai kewenangan menangkap pelaku pencurian ikan ketika pencurian itu dilakukan di wilayah laut parairan nusantara yauitu laut teritorial $12 \mathrm{Mil}$, maka kewenangan penangananya adalah kewenangan polisi air Polda Kepri untuk melakukan penangkapan dan penyidikan. TNI Angkatan Laut memliliki kewenangan untuk kasus pencurian ikan yang dilakukan di wilayah laut zona ekonomi ekslusif (ZEE) yaitu diwilayah 12 mil laut dari garis pangkal laut teritorila, yaitu laut yang wilayahnya terletak di luar laut teritorial. Maka pencurian ikan yang terjadi diwilayah ZEE menjadi kewenangan TNI Angkatan Laut untuk melakukan penangkapan dan penyidikanya. Hal ini sesuai dengan Peraturan Pemerintah Nomor 27 Tahun 1983 yang telah dipebaharui dengan Peraturan Pemerintah Nomor 92 Tahun 2015. 
Sedangkan Penyidik Pegawai Negaeri Sipil Dinas Kelautan dan Perikanan Provinsi Kepulauan Riau memiliki kewenangan di wilayah laut pantai, jika pencurian ikan atau pencurian ikan terjadi di laut pantai, maka PPNS Dinas Kelautan dan Perikanan Provinsi Kepulauan Riau yang memiliki kewenangan untuk melakukan penyidikanya. Kasus-kasus tersebut kemudian dilanjutkan ke pihak Kejaksaan dan kejaksaan yang akan melanjutkan rencana tuntutan. Rencana tuntutan ini dilaksanakan juga berhubungan dengan pihak Kejaksaan Tinggi dan Kejaksaan Agung. Dimana ketika kasus pencurian ikan dilakukan oleh kapal asing maka rencana tuntutanya harus ditetapkan oleh Kejaksaan Agung, sementara jika pencurian ikan dilakukan oleh kapal Indonesia, maka rencana tuntutan akan di tentukan oleh Kejaksaan Tinggi.

Setelah mendapatkan kepastian dari Kejaksaan Agung maupun Kejaksaan Tinggi maka kasus pencurian ikan ini akan disidangkan dan menjadi kewenangan Pengadilan Perikanan Pengadilan Negeri untuk menanganinya dan dari data yang didapatkan di Pengadilan Perikanan Pengadilan Negeri Tanjungpinang terdapat kasus pencurian ikan sepanjang tahun 2016 ada 30 kasus, tahun 2017 terdapat 51 kasus dan tahun 2018 pertanggal 10 September terdapat 20 kasus.Sementara Direktorat PSDKP mempunyai kewenangan terkait pencurian ikan adalah dalam hal pelaksanaan dan evaluasi penanganan pelanggaran sumber daya kelautan dan perikanan, yang akan berkoordinasi dengan Pengadilan Negeri dan Kejaksaan dalam hal pengawasan pelaku pencurian ikan yang terjadi di wilayah kepri yaitu Pangkalan PSDKP Batam.

Menganalisa kasus Htein Lin Aung yang berkebangsaan Myanmar yang di putuskan oleh pengadilan menyatakan Terdakwa HTEIN LIN AUNG telah terbukti secara sah dan meyakinkan bersalah melakukan tindak pidana Perikanan "Dengan sengaja menggunakan alat penangkap ikan yang menggangu dan merusak keberlanjutan sumber daya ikan di kapal penangkap ikan, di Wilayah Pengelolaan Perikanan Republik Indonesia". Menjatuhkan pidana kepada Terdakwa Htein Lin Aung oleh karena itu dengan pidana penjara selama 2 (dua) tahun dan denda sebesar Rp 1.500.000.000,-(satu milyart lima ratus juta rupiah), dengan ketentuan apabila denda tidak dibayar, maka diganti dengan pidana kurungan selama 4 (empat) bulan; Menetapkan lamanya masa penahanan yang telah dijalani oleh Terdakwa dikurangkan seluruhnya dari Pidana yang dijatuhkan; Menetapkan Terdakwa tetap berada dalam tahanan; Menetapkan barang bukti dalam perkara ini berupa 1 ( satu ) unit Kapal KM. KHF $1917, \pm 100 \mathrm{Kg}$ (lebih kurang seratus kilogram) ikan campur, sudah dimusnahkan berdasarkan Penetapan Ketua Pengadilan Negeri Batam Nomor. Nomor.17/Pen.Pid/2016/PN.BTM, tanggal 23 Maret 2016, 1 (satu) Unit alat tangkap jaringTrawl, 1 (satu) Unit alat Navigasi GPS Plotter/Sounder MMEC-APS 832mk2, 1 (satu) Unit alat komunikasi Radar JMC V-3300P, 1 (satu) unit Kompas Magnet Tokyo Compass, 1 (satu) buah buku dokumen lessen vessel dan peralatan penangkap ikan untuk dapat dimusnahkan.

Dengan putusan tersebut ini memberi bukti bahwa instansi terkait telah melaksanakan tugasnya memberikan perlindungan hukum sesuai dengan teori perlindungan hukum yang di sampaikan oleh Philipus M Hadjon bahwa perlindungan 
hukum bagi rakyat dilakukan oleh pemerinah dengan tindakan yang bersifat preventif dan represif, dimana tindakan pencegahan dilaksanakan dengan membentuk aturan perundang-undangan tentang pencurian ikan dan tindakan represifnya dilakukan dengan tindakan penjatuhan hukuman yang telah diberikan pada pelaku pencurian ikan dalam penelitian ini.

Maka untuk mendapatkan perlindungan hukum yang menjadi cita cita masyarakat semua instansi terkait dalam hal ini kasus pencurian ikan di daerah perbatasan Provinsi Kepulauan Riau, semua instansi terkait yang berwenang dalam penanganan kasus pencurian ikan harus melaksanakan kewajiban dan menindaki setiap pelaku pencurian ikan sesuai dengan kewenangan basing-masing sesuai dengan ketentuan perundangundangan yang berlaku dengan penuh tanggung jawab. Dan masyarakat juga harus mendukung segala upaya pencegaran dan penindakan terhadap pelaku pencurian ikan sehingga perlindungan hukum dapat terwujud yang kemudian negara ini dapat melakukan proses pembangunan sesuai dengan teori Hukum pembangunan Mochtar Kusumatmadja bahwa ketertiban atau keteraturan dalam rangka pembaharuan atau pembangunan merupakan sesuatu yang diinginkan, bahkan dipandang mutlak adanya dan hukum dalam arti kaidah atau peraturan hukum memang dapat berfungsi sebagai alat pengatur atau sarana pembangunan dalam arti penyalur arah kegiatan manusia yang dikehendaki ke arah pembaharuan.

\section{Hambatan dan solusi yang di hadapi instansi berwenang dalam penegakan hukum terkait pencurian ikan di wilayah perbatasan Kepulauan Riau}

Dalam melaksanakan tugas dalam penangangan pencurian ikan yangterjadi diwilayah Provinsi Kepri setiap instansi terkait mengalami hambatan dan solusi dalam memanggani kasus pencurian ikan. Dan untuk menjawab rumusan masalah ini peneliti paparkan hasil penelitian yang peneliti lakukan lewat wawancara pada instansi berwenang di wilayah perbatasan kepulauan Riau.

Diantara kendala yang dihadapi tersebut adalah:

\section{Direktorat Polisi Air Polda Kepulauan Riau}

Hambatan yang dihadapi oleh direktorat Pol Air Polda Kepri dalam penegakan hukun bagi pelanggaran Pencurian ikan di Kepulauan Riau menurut Bapak Ahmad Wahyudi,SH, MH adalah

a. mencakup wilayah Kepulauan Riau yaitu 95,5\% adalah lautan yang sangat luas.

b. keterbatasana sarana dan prasarana armada yang kurang

c. faktor cuaca serta personil yang terbatas.

Hambatan diatas akan memperlambat gerak dalam menangani pelanggaran yang terjadi di laut.

Sedangkan solusi yang telah dilakukan oleh pihak kepolisian adalah meningkatkan jam patroli di wilayah perbatasan dan terus mengajukan anggaran untuk pengadaan tambahan armada, personil dan prasarana guna dapat melaksanakan tugas dilapangan dengan lebih baik lagi. 


\section{Dinas Kelautan dan Perikanan Provinsi Kepulauan Riau}

Sedangkan hambatan yang dihadapi oleh Dinas Kelautan dan Perikanan Provisi Kepulauan Riau yang disampaikan oleh Bapak Sahrizan, ST Kepala seksei Pengawasan Sumberdaya Kelautan dan Perikanan adalah kurangnya perlengkapan armada, terbatasnya personil dan pendanaan dalam melaksanakan tugasnya. Kendala lain yang dihadapi adalah selama persidangan berlangsung maka dan biaya hidup dari pelaku Pencurian ikan ditanggung oleh Dinas Kelautan. Semakin lama proses semakin besar biaya yang harus dikeluarkan.

Sedangkan solusi yang diambil adalah dengan melakukan koordinasi yang lebih baik lagi dengan instansi instansi terkait dalam penanganan kasus pencurian ikan dan mengajukan penambahan personil lapangan dan armada dan pelatan yang mendukung dan cukup untuk melaksanakan tugas.

\section{Pengadilan Perikanan pada Pengadialan Negeri Tanjungpinang}

Hambatan yang ditemukan dalam melaksanakan tugas di Peradilan Perikanan Pengadilan Negeri Tanjungpinang disampaiakan oleh Hakim Pengadilan Peradilan Perikanan bapak Ir. Syafriyulis, MM adalah sering molornya rencana tuntutan dari Jaksa Penuntut Umum serta keterbatasan penerjemah dalam menyelesaikan kasus pencurian ikan negara lain. Rencana tuntutan dilakukan oleh Kejaksaan agung bagi pencurian ikan diatas 12 Mil sampai 200 Mil sedangkan yang terjadi di bawah 12 mil tuntutan dilakukan oleh kejaksaan tinggi. Lamanya Rentun yang dilakukan akan berakibat berlarutnya kasus yang ditangani. Hukuman yang dijatuhkan bukan dalam bentuk pidana kurungan tapi dalam bentuk denda dan penguasaan atas kapal. Hukuman denda yang dijatuhkanpun kadang tidak dapat dibayar sehingga negara indonesia tetap dalam keadaan yang dirugikan. Solusi nya adalah dengan meningkatkan koordinasi antar instansi terkait yaitu mengaktifkan semua stekholder, memperkuat pengamanan untuk pencegahan dan meningkatkan koordinasi dalam rencana tuntutan dan pengadaan penerjemah untuk kasus pencurian ikan yang dilakukan oleh orang asing.

\section{TNI Angkatan Laut Kepulauan Riau.}

Dalam menjalankan tuganya TNI Angkatan Laut sering kali mendapat hambatan yaitu luasnya wilayah laut Provinsi Kepri yaitu 95,5 \%, keterbatasan sarana dan prasarana, serta kondisi cuaca dan personil yang terbatas. Solusi yang dilakukan adalah dengan meningkatakan koordinasi dan mengajukan anggaran untuk menambah aramada juga menabah anggota persnonil lapangan. 


\section{E. Kesimpulan}

Kasus pencurian ikan yang terjadi di wilayah perbatasan Provinsi Kepulauan Riau menjadi suatu masalah yang harus diselesaikan oleh berbagai instansi, dan tidak dapat diselesaikan secara mandiri. Adapun Instasi yang berwenang menangani kasus Pencurian ikan ini melibatkan pemerintah daerah dan instansi vertikal dan TNI juga Polri. Adapun instasi-instansi berewenang tersebut adalah Direktorat Polisi Air Polisi Daerah Kepulauan Riau, Dinas Kelautan dan Perikanan Provinsi Kepulauan Riau, Pengadilan Perikanan pada Pengadialan Negeri Tanjungpinang dan TNI Angkatan Laut Kepulauan Riau. Dimana instansi satu dan yang lainya saling bekerjasama, bahu membahu dalam menangani setiap kasus pencurian ikan yang terjadi di wilayah perbatasan, baik pencurian ikan yang dilakukan oleh kapal asing maupun kapal tempatan.

Masing masing penegak hukum melakukan Tugas dan fungsi masing masing baik dalam hal menangkap ( Pol Air dan TNI AL ), penyidikan dan penuntutan ( Kejaksaan Agung, Kejaksaan Tinggi, PPNS Kelautan ) peseridangan oleh Pengadilan serta evaluasi oleh dinas kelautan. Polisi air mempunyai kewenangan menangkap pelaku pencurian ikan di wilayah laut parairan nusantara yaitu laut teritorial 12 Mil, maka kewenangan penangananya adalah kewenangan polisi air Polda Kepri untuk melakukan penangkapan dan penyidikan . TNI Angkatan Laut memliliki kewenangan untuk kasus pencurian ikan di wilayah laut zona ekonomi ekslusif (ZEE) yaitu diwilayah 12 mil laut dari garis pangkal laut teritorila, maka TNI Angkatan Laut yang melakukan penangkapan dan penyidikanya. Sedangkan Penyidik Pegawai Negaeri Sipil Dinas Kelautan dan Perikanan Provinsi Kepulauan Riau memiliki kewenangan di wilayah laut pantai, jika pencurian ikan atau pencurian ikan terjadi di laut pantai, maka PPNS Dinas Kelautan dan Perikanan Provinsi Kepulauan Riau yang memiliki kewenangan untuk melakukan penyidikanya.

Masing masing instansi mempunyai kendala dalam menangani masalah pencurian ikan, luas wilayah, personil, cuaca, sarana dan prasarana yang minim serta hukuman yang tidak berpihak pada keuntungan indonesia sebagai korban dari kegiatan pencurian ikan. Dan solusi yang telah dilaksanakan adalah dengan meningkatkan koordinasi antar satu instansi dan yang lainya atau dengan semua stekholder dalam kasus pencurian ikan dan mengajukan penganggaran untuk menambahan armada, sarana dan prasarana juga pengajuan penambahan personil dilapanangan, termasuk berkoordinasi dengan pihak kejaksaan dalam waktu rencana tuntutan yang diberikan ke Pengadilan negeri agar kasus pencurian ikan dapat segera diadili dan dijatuhkan putusan. 


\section{DAFTAR PUSTAKA}

\section{Buku}

Anonim, 2003, "Pencurian ikan in the Southern Ocean: The Problem, Practices and Perpetrators" Australian Antartic Magazine 5 Winter

APEC Fisheries Working Group, 2008, Assessment of Impact of Illegal, Unreported, Unregulated (IUU) Fishing in the Asia-Paific. Asia-Pasific Economic Coorporation Secretariat, Singapura

Arif Djohan Tunggal, 2014, Aspek-Aspek Hukum Laut Pendekatan Tanya Jawab, Harvarindo, Jakarta

Ashshofa Burhan, 2007, Metode Penulisan Hukum, Rineka Cipta, Jakarta

Bernard L. Tanya, Yoan N. Simanjuntak dan Markus Y. Hage

Boer Mauna, 2011, Hukum Internasional Pengertian, Peranan dan Fungsi Dalam era Dinamika Global, Alumni, Bandung

Bodgan \& Taylor, 1993, Dasar-dasar Penulisan Kualitatif, terjemahan oleh A. Khozin Afandi, Penerbit Usaha Nasional, Surabaya

Dellyana, Shant 1988,Konsep Penegakan Hukum. Yogyakarta: Liberty

Dhiana Puspitawati, 2017, Hukum Laut Internasional, Kencana, Depok

Didik Mohamad Sodik, 2011, Hukum Laut Internasional dan Pengaturanya di Indonesia, Refika Aditams, Bandung

Dewi Indira Biasane, 2009, Kerjasama Maritim Asia Tenggara dalam Penanggulangan Penangkap Ikan Ilegal; Studi Kasus: Penangkap Ikan Ilegal di Wilayah Pengelolaan Perikanan Republik Indonesia, penelitian Fakultas Ilmu Sosial dan Politik Universitas Indonesia, Jakarta

Dikdik Mohamad Sodik, 2011, Hukum Laut Internasional Dan Pengaturannya Di Indonesia, Refika Aditama, Bandung

Direktorat Jenderal Pengawasan dan Pengendalian Sumber Daya Kelautan dan Perikanan Departemen Kelautan dan Perikanan Republik Indonesia, 2006, Departemen Kelautan dan Perikanan, Jakarta

Edy Sofyan, Kebijakan Pertahanan Pertanahan di Perbatasan Maritim, Majalah suara Perbatasan, Edisi IX Juni 2016

Gerd Winter, 2009, Towarsd Suistainable Fisheries Law, IUCN Publications Services, Switzerland

Gianni.M dan W. Simpson, 2005, The Changing Nature of High Sea Fishing. How Flag of Convenience Provide Cover for Illegal, Unreported and Unregulated Fishing. 
WWF dan Departement of Agriculture, Fisheries and Forestry, Australian Government

Hasil wawancara dengan Humas PN Ranai, Nanang Dwi Kristanto SH. M.Hum, Jumat (9/6/2017).

Lili Rasjidi daN I.B Wysa Putra, Hukum Sebagai Suat Sistem, Bandung, Remaja Remaja Rusdakarya, 1993

Komaruddin, , 1984, Kamus Riset, Angkasa, Bandung

Maimuna Renhoran, 2012, Strategi Penanganan Illegal, Unreported and Unregulated (IUU) Fishing di Laut Arafura, penelitian Fakultas Hukum

Marhaeni Ria Siombo, Hukum Perikanan Nasional dan International, Jakarta, Gramedia Pustaka Utama, 2010

Maria Alfons, "Implementasi Perlindungan Indikasi Geografis Atas Produk-produk Masyarakat Lokal Dalam Perspektif Hak Kekayaan Intelektual", Ringkasan Disertasi Doktor, (Malang: Universitas Brawijaya, 2010)

Marwan Mas, Pengantar Ilmu Hukum, Bogor, Ghalia Indonesia, 2004

Marzuki Peter Mahmud, 2009, Penelitian Hukum, Cet.5, Kencana, Jakarta

Mochtar Kusumaatmadja, 1986, Hukum Laut internasional, Binacipta, Bandung

Moh. Nasir, Metode Penulisan, Ghalia, Indonesia

Nunung Mahmuda, 2015, "Illegal Fishing Pertanggungjawaban Pidana Korporasi di

Wilayah Perairan Indonesia", Sinar Grafika, Jakarta

Peter Salim, 2003, The Contemporary English Indonesian Dictionary, Modern English

Press, Jakarta

Phillipus M. Hadjon, "perlindungan hukum Bagi Rakyat Indonesia”, (Surabaya: PT.

Bina Ilmu, 1987)

Satijipto Raharjo, 'Ilmu Hukum', (Bandung: PT. Citra Aditya Bakti, 2000)

Section II International Plan of Action to Prevent, Deter and Eliminate Illegal,

Unreported, and Unregulated Fishing, Food And Agriculture Organization of The United Nations, Rome, 2001.

Soerjono Soekanto,2006,Pengantar Penelitian Hukum,Universitas Indonesia (UI Press),Jakarta

Sudarto, Hukum dan Hukum Pidana, Alumni, Bandung,2007.

Sunaryati Hartono, "Politik Hukum Menuju Satu Sistem Hukum Nasional", (Bandung: Alumni, 1991)

Supanto, Perlindungan Hukum Wanita, "http: //supanto. staff.hukum.uns.ac.id ", (Diakses Pada Tanggal 07 Agustus 2015).

Tanpa nama, Penataan Pengamanan Wilayah Maritim Guna Memelihara Stabilitas dalam RangkaMenjaga Kedaultan NKRI, Jurnal Kajian Lemhanas RI, Edisi 14, 
Desember 2012

T.May Rudy, 2002, Hukum Internasional 2, Rafika Aditama, Bandung

United Nations, 1988, The Work of the International Law Commission, Fourth Edition, United Nations Publication, New York

Universitas Indonesia, Jakarta, (selanjutnya disingkat Maimuna Renhoran I)

Victor P. H. Nikijuluw, 2008, Blue Water Crime: Dimensi Sosial Ekonomi Perikanan Ilegal, PT Pustaka Cidesindo, Jakarta

Wirjono Prodjodikoro, 1984, Hukum Laut Bagi Indonesia, Sumur Bandung, Jakarta

\section{Website}

http://economormormy.okezone.com/read/2018/01/07/320/923024/2013-39-kapal-

asing-ilegalcuri-ikan-ri di akses pada tanggal 21 Maret tahun 2018 Pukul 16.00 WIB.

http://finance.detik.com/read/2014/07/08/131735/2631219/4/malaysia-dan-vietnam-

negaraasal-pencuri-ikan-terbanyak-di-laut-ri diakses pada tanggal 29 Maret Tahun 2018 Pukul 19.00 WIB.

http://www.kkp.go.id/index.php/arsip/c/1383/Perairan-Natuna-Paling-Rawan-

Pencurian-Ikanoleh-Kapal-Asing-/ di akses pada tanggal 29 Maret Tahun 2018 Pukul 12.04 WIB.

http://statistik.kkp.go.id/index.php/arsip/c/?category_id=3 Diakses tanggal 15 April 2018 jam 15.00

\section{Peraturan Perundang-Undangan}

Undang-UndangDasar Negara Republik Indonesia Tahun 1945.

United Nations Convention on the Law of the Sea 1982.

International Plan of Action to Prevent, Deter and Eliminate Illegal, Unreported and Unregulateg Fishing 2001.

Code of Conduct for Responsile Fisheries 1995.

Regional Plan of Action to Promote Responsible Fishing Practices including Combating Illegal, Unreported and Unregulated (IUU) Fishing in the Region 2007.

Undang-Undang Nomor 31 Tahun 2004 tentang Perikanan dan Undang-Undang Nomor 45 Tahun 2009 tentang Perubahan Atas Undang-Undang Nomor 31 Tahun 2004 tentang Perikanan.

Undang-Undang Nomor 27 Tahun 2007 Tentang Pengelolaan Wilayah Pesisir dan Pulau-Pulau Kecil. 
Peraturan Pemerintah Nomor 60 Tahun 2007 Tentang Konservasi Sumber Day Ikan. Putusan Pengadilan Negeri Tanjungpinang Nomor:12/Pid.Sus.Prkn/2016/PN.TPg. Putusan Pengadilan Negeri Tanjungpinang Nomor: 7/Pid.Sus-PRK/2016/PN Tpg. 